\title{
The characteristics of the patients in mass public shootings among coup attempt in Turkey: A single-center hospital response
}

\author{
[D Kurtuluş Açıksarı, M.D., ${ }^{1}$ @ Mehmet Koçak, M.D., ${ }^{2}$ ๑ Görkem Alper Solakoğlu, M.D., ${ }^{3}$

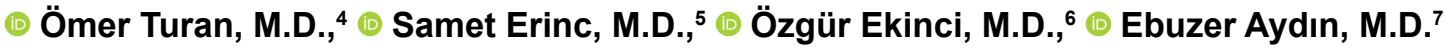

\begin{abstract}
${ }^{1}$ Department of Emergency Medicine, İstanbul Medeniyet University Faculty of Medicine, İstanbul-Turkey
${ }^{2}$ Department of Emergency Medicine, Health Science University, Fatih Sultan Mehmet Training and Research Hospital, İstanbul-Turkey

${ }^{3}$ Department of Emergency Medicine, Göztepe Training and Research Hospital, İstanbul-Turkey

${ }^{4}$ Department of Forensic Medicine, İstanbul Medeniyet University Faculty of Medicine, İstanbul-Turkey

${ }^{5}$ Department Orthopedics, Health Science University, Şişli Etfal Training and Research Hospital, İstanbul-Turkey

${ }^{6}$ Department of General Surgery, İstanbul Medeniyet University Faculty of Medicine, İstanbul-Turkey

${ }^{7}$ Department of Cardiovascular Surgery, İstanbul Medeniyet University Faculty of Medicine, İstanbul-Turkey
\end{abstract}

\section{ABSTRACT}

BACKGROUND: Turkey is an experienced country for both military and civilian mass casualties that arise from explosions and shootings by various terrorist groups. In this study, we aimed to investigate the characteristics of patient flow admitted to our hospital caused by primarily gunshot wounds during the coup attempts on the $15^{\text {th }}$ of July.

METHODS: This descriptive, retrospective study included a total of 50 patients who were injured during a coup attempt on the date of July 15, 2016, and admitted to our emergency department (ED). Demographic characteristics, anatomical injury sites, postoperative clinical outcomes, and hospitalization settings were recorded. The Glasgow Coma Scale (GCS), Trauma and Injury Severity Score (TRISS), Abbreviated Injury Scale (AIS), Revised Trauma Score (RTS) and Injury Severity Score (ISS) were used to measure the severity of injuries.

RESULTS: A total of 63 medical personnel voluntarily reached the ED within two hours. Extremity injuries were the most common injuries. The mean RTS, GCS, and TRISS scores did not differ significantly between the patients discharged from the ED and the patients who were hospitalized $(p>0.05)$. However, there was a statistically significant difference in the ISS scores $(p<0.00 \mathrm{I}$, independent t-test). There was no statistically significant difference in the GCS and RTS scores between the discharged and hospitalized patients, although the ISS scores were higher in hospitalized patients $(p>0.05$ and $p<0.00$ I, respectively). A total of 33 patients $(66 \%)$ were admitted to the hospital for follow-up and/or surgical intervention. Five (10\%) of the patients were hospitalized for more than 14 days.

CONCLUSION: The management of each disaster is unique. Armed conflicts result in gunshot wounds, and preparations must be focused on surge capacity and a prolonged hospital stay of the patients. In our study, the length of stay in the hospital decreased after the arrival of volunteer staff to the ED, but we should note that the ISS increased. Hospital disaster plans should be reorganized not only for ED but also for the whole hospital.

Keywords: Emergency department; gunshot; injury severity score; mass casualty incidents.

Cite this article as: Açıksarı K, Koçak M, Solakoğlu GA, Turan Ö, Erinc S, Ekinci Ö, et al. The characteristics of the patients in mass public shootings among coup attempt in Turkey: A single-center hospital response. Ulus Travma Acil Cerrahi Derg 2020;26:67-73.

Address for correspondence: Kurtuluş Açıksarı, M.D.

İstanbul Medeniyet Üniversitesi Tıp Fakültesi, Acil Tıp Anabilim Dalı, İstanbul, Turkey

Tel: +90 216 - 2803333 E-mail: kurtulusaciksari@gmail.com

Ulus Travma Acil Cerrahi Derg 2020;26(I):67-73 DOI: 10.14744/tjtes.2019.9682I Submitted: 17.07.2019 Accepted: 06.1I.2019 Online: 30.12.2019

Copyright 2019 Turkish Association of Trauma and Emergency Surgery 


\section{INTRODUCTION}

Terrorism is defined as all criminal acts directed against a state. As terrorism sweeps the globe, physicians are obliged to treat patients with a range of injuries requiring a broadening of their skills and knowledge. ${ }^{[1]}$ Mass casualty incidents (MCls) are often considered infrequent events in developed countries. However, Turkey is an experienced country for both military and civilian mass casualties that arise from explosions and shootings by various terrorist groups, namely the Kurdistan Workers' Party (PKK), Islamic State of Iraq and Syria (ISIS), and so forth. ${ }^{[2]}$

Turkey faced a coup attempt in which 248 individuals died, and 2,196 wounded across the country on the date of July 15, 2016. Only in Istanbul province, more than 800 individuals were injured, and approximately 90 individuals died. ${ }^{[3]}$ Most relevant places that coup protesters gathered in the east coast of Istanbul were the Bosporus Bridge, which was named as the 15 July Martyrs bridge later, Çengelköy district, and Turk Telekom headquarters where a total of 50 individuals were killed. The trauma mechanisms were mostly shootings, followed by assaults, motor and military vehicle accidents, and falls. ${ }^{[3]}$

Although there are some exceptions, mass casualties arise from terrorist activities tend to cease in a short period. ${ }^{[4]}$ In the present study, we aimed to investigate the wounding patterns of the patients resisting the coup attempt, which caused 12 hours of patient flow to the emergency department (ED) of a tertiary hospital caused by primarily gunshot wounds.

\section{MATERIALS AND METHODS}

This descriptive, retrospective, clinical study included a total of 50 patients who were injured during the coup attempt on the date of July 15, 2016, and admitted to our ED. Patient records were retrieved from the hospital database. Data, including age, sex, time of admission, type and localization of the injury, relevant clinics to perform surgery, operation types, length of stay (LOS) in the intensive care unit and hospital, blood transfusion requirement, radiological imaging modalities, and reports, were recorded. The Glasgow Coma Scale (GCS), Trauma and Injury Severity Score (TRISS), Abbreviated Injury Scale (AIS), Revised Trauma Score (RTS), and Injury Severity Score (ISS) were used to measure the severity of injuries. ${ }^{[5]}$

This study was approved by the local ethics committee (date: 06.06.2017, no: 2017/0160).

\section{Organization of the ED}

At the first stage, when the coup attempt began, injured individuals were expected to be admitted to hospitals around Istanbul province. After the confirmation of the event, ED and intensive care units were informed, and the hospital disaster plan was initiated under the leadership of the chief physician. At the second stage, the hospital staff was alerted according to the hospital disaster plan to meet the ED in a coordinated manner. The blood bank was informed, and additional supplies were requested from the hospital repository. In the third stage, the ED was reorganized. Nearly 40 patients who were triaged as green were informed about the event in the waiting area. On the evening of the event, our ED was operating at full capacity ( 29 beds). To increase capacity in our hospital, the patients who were less critical were either admitted to the available wards or discharged for later follow-up. In the ED, 15 beds in the ward and four beds in the resuscitation area were evacuated. The corridors in the ED were redesigned and prepared as the observation area to be used in case of any need. Green areas for non-serious injuries, yellow for moderate injuries, and red for serious and life-threatening injuries were redefined. The morgue was prepared. Since the events lasted within a relatively brief period, there was no shortage of supplies with available appropriate medical equipment and surge capacity in our hospital.

The incident lasted about 12 hours. Ordinarily, in the evening on the date of July 15, 2016, five nurses, five emergency medicine residents, and two emergency medicine specialists were on duty. Sixty-three medical personnel voluntarily reached the ED within three hours between 11:00 PM-02:00 AM. The voluntary healthcare personnel consisted of two emergency medicine specialists, four emergency medicine residents, two orthopedic surgeons, three general surgeons, one anesthesiologist, one plastic surgeon, one cardiovascular surgeon, one family medicine specialist, one chief physician (nephrologist), one pediatric surgeon, one Doctor of Medical History and Ethics, and 28 nurses, eight anesthesia technicians, one midwife, six health officers, one driver, and one clinical support personnel. On July 16, 2016, at 08:00 AM, the shift change was accomplished according to the current schedule, and the volunteer staff arrived at the hospital sustained to work in the hospital until the end of the events was announced.

\section{Statistical Analysis}

Statistical analysis was performed using the SPSS for Windows version 22.0 software (IBM Corp., Armonk, NY, USA). Descriptive data were expressed in mean \pm standard deviation (SD), median (min-max), or number and frequency. Normally distributed variables were compared using the Student's ttest, while non-normally distributed variables were compared using the Mann-Whitney $U$ test. A p-value of $<0.05$ was considered statistically significant.

\section{RESULTS}

During the 12-hour period (I2:00 AM-12:00 PM of July I6), a total of $15 \mathrm{I}$ patients were admitted to our hospital. According to the triage codes, $85,36,30$ were presented in green, 
yellow, and red, respectively. Triage codes did not alter during the follow-up of the patients in the ED. Of these patients, 5 I were admitted to the hospital due to injuries during the coup attempt. One patient was excluded from this study, as he was found to be dead before the hospital admission. Of the 50 patients, 49 were male and one patient was female with a mean age of $35.38 \pm 10.1$ (range, 17 to 65 ) years. Demographic characteristics, anatomical injury sites, postoperative clinical outcomes, and hospitalization settings are shown in Table I. The most common injury was extremity injury (53\%), fol-

Table I. Clinical characteristics of the victims

\begin{tabular}{|c|c|c|}
\hline & $\mathbf{n}$ & $\%$ \\
\hline \multicolumn{3}{|l|}{ Gender } \\
\hline Male & 49 & 98 \\
\hline Female & 1 & 2 \\
\hline \multicolumn{3}{|l|}{ Age (year) } \\
\hline $17-29$ & 15 & 30 \\
\hline $30-44$ & 30 & 60 \\
\hline $45-59$ & 3 & 6 \\
\hline$>60$ & 2 & 4 \\
\hline \multicolumn{3}{|l|}{ Injured body region } \\
\hline Lower extremity & 25 & 53 \\
\hline Upper extremity & 12 & 25 \\
\hline Head \& neck & 5 & 10 \\
\hline Facial & 4 & 8 \\
\hline Chest & 2 & 4 \\
\hline Abdomen & 2 & 4 \\
\hline \multicolumn{3}{|l|}{ Post-operative diagnosis } \\
\hline Debridement & 19 & 38 \\
\hline Foreign body excision & 6 & 12 \\
\hline Fracture (NOM*/immobilized) & 6 & 12 \\
\hline Fracture / require surgery & 10 & 20 \\
\hline Intracranial hemorrhage & 4 & 8 \\
\hline Maxillofacial & 4 & 8 \\
\hline Gastrointestinal rupture & 1 & 2 \\
\hline \multicolumn{3}{|l|}{ The total length of stay } \\
\hline Discharged directly from $\mathrm{ED}^{+}$ & 15 & 30 \\
\hline I-14 days & 27 & 54 \\
\hline$>14$ days & 6 & 12 \\
\hline Transferred from ED to another hospital & 2 & 4 \\
\hline \multicolumn{3}{|l|}{ Injury severity scores } \\
\hline Minor injury (ISS I-8) & 34 & 74 \\
\hline Moderate injury (ISS 9-15) & 5 & 6 \\
\hline Severe injury (ISS I6-24) & 5 & 8 \\
\hline Critical injury (ISS $\geq 25$ ) & 6 & 12 \\
\hline
\end{tabular}

+ED: Emergency Department; "NOM: Non-operative management. lowed by head and neck injuries (10\%). Nine (18\%) of the patients with gunshot wounds were transferred to the hospital by ambulance. Three of these patients were referred from external centers. The majority of the patients with gunshot wounds were admitted to the ED between 03:00 AM-09:00 AM (n=37, 78.7\%) (Fig. I).

Of the 15 patients (23.4\%) followed in the ED, 12 of them were discharged within eight hours and three within two hours. The ISS scores of these patients were below 4, indicating minor injuries. Three patients who were admitted to the ED were transferred to the external centers after the initial intervention, due to the inadequacy of the operating theaters in the hospital. One patient arrived at 02:07 AM with a deep tendon-muscle-artery cut in the arm, one patient arrived at 03:30 AM with a bullet fragment injuring the femoral artery, and one patient arrived at 04:00 AM with an open wound in the popliteal region. One of these patients was referred back to the referral hospital due to inadequate operating conditions in our hospital.

The patient flow with injury severity scores is given in Figure

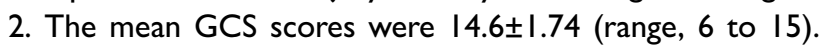
The mean ISS scores were $21.75 \pm 10$ (range, I to 34). A total of 39 patients $(78 \%)$ had ISS scores fewer than 16; II patients (22\%) were considered major trauma. The mean RTS, GCS, TRISS scores did not differ significantly between the patients who were discharged from ED and the patients who were

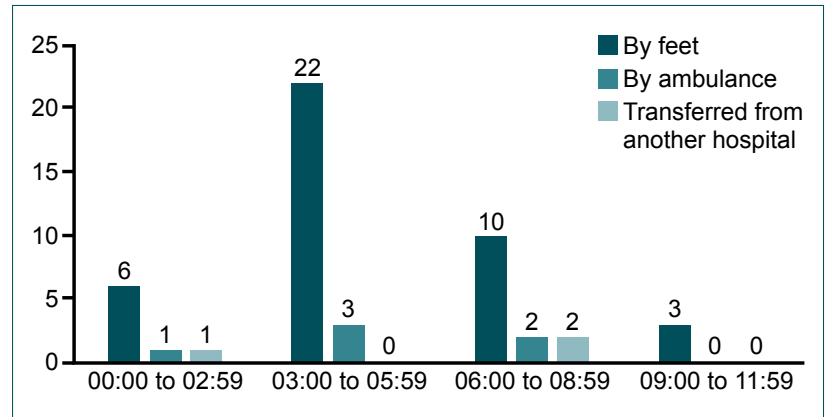

Figure 1. Hospital arrival time interval of the patients.

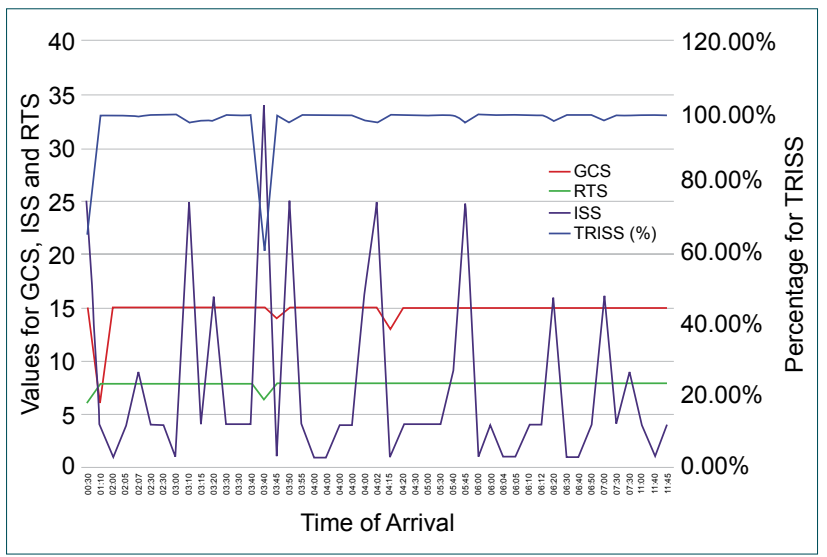

Figure 2. Distribution of the GCS, ISS, RTS, TRISS values according to arrival time. 

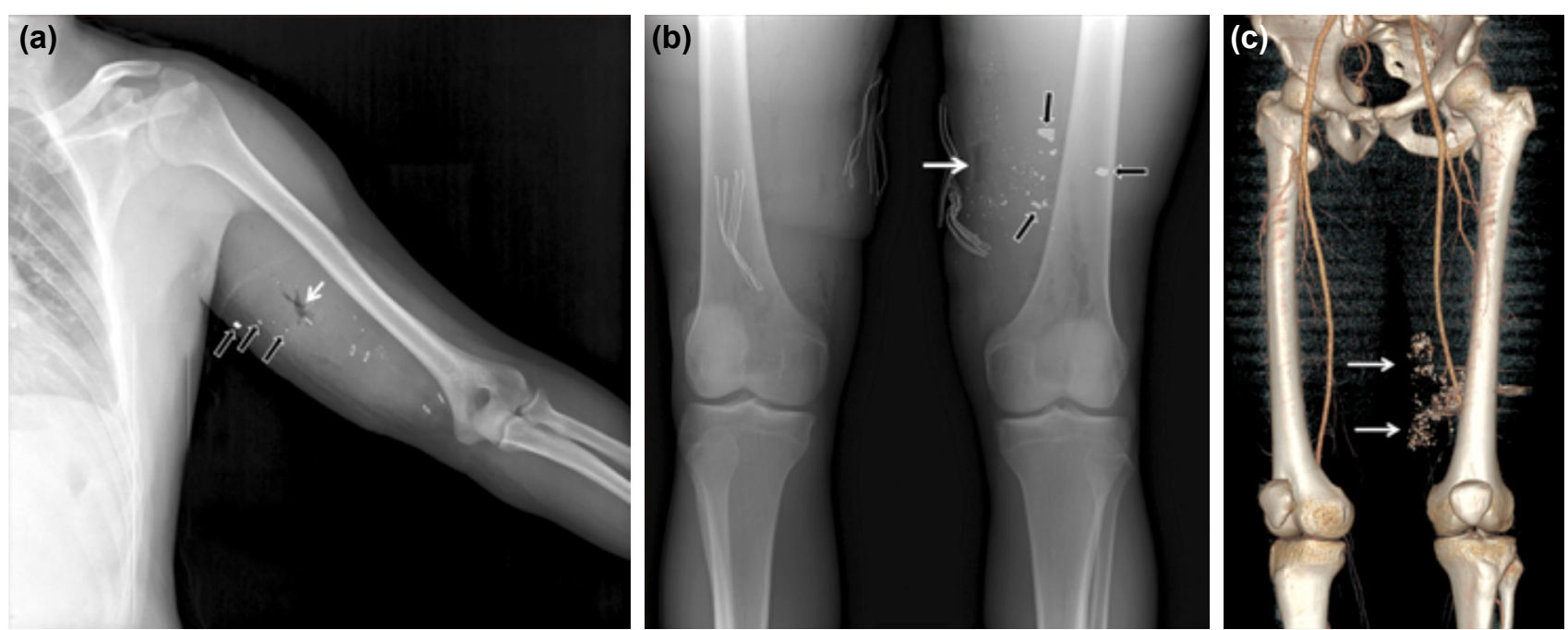

Figure 3. Selected radiographic images of wounded patients. (a) A 21-year-old male patient with an anterior-posterior left arm radiograph. Hypodense area (white arrow), which is compatible with the open wound and soft tissue loss, is observed in the left flank. Metallic foreign bodies (black arrows) are observed in the soft tissue. The shrapnel pieces have been verified in debridement of the wound. (b) 21 -year-old male patient, bilateral anteroposterior weight-bearing knee radiograph. Metallic foreign bodies compatible with soft tissue loss (white arrow) and shrapnel fragments in soft tissue are observed in the middle distal part of the left thigh (black arrows). There is no pathology in the left femur. (c) A 21-year-old male patient. Three-dimensional computed tomography angiography images show many metallic millimeter-sized foreign bodies (white arrows) in the soft tissue in the distal section of the left knee. Shrapnel pieces have been verified on the wound debridement. Superficial femoral and popliteal arteries are released.

hospitalized ( $p>0.05)$. However, there was a positive and significant correlation between the ISS and LOS in the hospital $(p<0.001, r=0.912)$.

A total of 33 patients $(66 \%)$ were admitted to the hospital for follow-up and/or surgical intervention. Five of the patients $(10 \%)$ were hospitalized for more than 14 days. Eighteen patients $(36 \%)$ were admitted to the orthopedics, seven (14\%) to the plastic and reconstructive surgery, four $(8 \%)$ to the neurosurgery, one $(2 \%)$ to the intensive care unit, one $(2 \%)$ to the general surgery, and one $(2 \%)$ to the thoracic surgery ward. Based on the postoperative diagnoses, 19 patients (38\%) underwent debridement for soft tissue trauma without a vascular injury, and 10 patients $(20 \%)$ required surgical intervention due to fractures, while six patients (12\%) were followed without surgical intervention. There were intracra- nial hemorrhages in four (8\%), vascular injury in four (8\%), and gastrointestinal perforation in one patient $(2 \%)$ who was urgently operated. Figure 3 demonstrates selected radiological images of the patients who had bullet fragments and vascular injuries. The LOS in the hospital and clinical features of patients are shown in Table 2.

When the first eight consecutive patients arrived, 12 staff was working in the ED, and the mean ISS scores were $5.75 \pm 8.26$ (range, I to 25 . While 75 staff was in the ED, the mean ISS scores of 42 patients who were admitted to the ED were $7.76 \pm 8.29$ (range, I to 34 ). There were no statistically significant differences in the ISS scores between the two groups $(p=0.206)$. Three patients $(37.5 \%)$ in the first group and 30 patients $(71.4 \%)$ in the second group were hospitalized. The mean LOS in the hospital in the first and

Table 2. Characteristics of the patients according to hospital length of stay

\begin{tabular}{|c|c|c|c|}
\hline$<24$ hr (I 5 patients) & I-7 days (22 patients) & 8-14 days (6 patients) & $>14$ days (5 patients) \\
\hline Laseration on face & Foreign body on the extremities* & Multiple bone fractures on feet ${ }^{*}$ & Complicated femur fractures* \\
\hline Laseration on scalp & Open, dirty wounds on extremities* & Humerus fracture & Subarachonid hemorrhage \\
\hline Toe fracture & Mandibula fracture* & Femur fracture* & Subdural hemorrhage \\
\hline Laseration on foot & Subdural hemorrhage* & Lomber fracture with & with scalp fracture \\
\hline Metacarp fracture & Gunshut on abdomen & femur fracture & Complicated mandibula \\
\hline Malleol fractures & Scapula fractures & & fractures* \\
\hline $\begin{array}{l}\text { Bullet hole in the feet, } \\
\text { elbow, shoulder* }\end{array}$ & Extremity fractures* & & \\
\hline
\end{tabular}

"More than one patient. 
Table 3. The comparison of the LOS and Injury Severity Score according to the number of staff in the emergency department

\begin{tabular}{lccccccc}
\hline & $\begin{array}{c}\text { Number of the } \\
\text { staff in ED }\end{array}$ & $\begin{array}{c}\text { Number of the } \\
\text { patients }\end{array}$ & Mean & $\begin{array}{c}\text { Standard } \\
\text { Deviation }\end{array}$ & Minimum & Maximum \\
\hline LOS at hospital & 12 & 3 & 11.19 & 12.32 & 4.04 & 25.42 \\
& 75 & 30 & 9.16 & 9.21 & 1.00 & 34.42 \\
ISS & 12 & 8 & 5.75 & 8.26 & 1 & 25 \\
& 75 & 42 & 7.76 & 8.29 & 1 & 34 \\
\hline
\end{tabular}

ED: Emergency department; LOS: Total length of stay.

second group was $11.19 \pm 12.32$ (range, 4.04 to 25.42 ) days and $9.16 \pm 9.21$ (range, I.0 to 34.42 ) days, respectively, indicating no statistically significant differences between the two groups $(p=0.725)($ Table 3$)$.

\section{DISCUSSION}

The MCls in which many individuals are affected and injured are the events that exceed the ordinary quality/quantity of service provided by emergency medical teams working in the field. ${ }^{[6]}$ The ability of hospital emergency response to major incidents depends on an exceptional incident management system that works well under normal circumstances, adequate supplies, and qualified personnel capable of performing on special occasions. ${ }^{[7]}$ From the view of the $\mathrm{MCls}$, we consider the events that took place on the date of July 15, 2016 "mega" which affected thousands of people in the society in a limited time and many different focal points, occurring suddenly and constraining the capacity of emergency response in the hospital management. ${ }^{[8]}$

At the time of coup attempt, although communication channels were intact between the Emergency Medicine System (EMS) and our hospital, there were roadblocks on the way of the ambulances, and the victims had difficulties in reaching the hospital on the night of the incident. Therefore, in the first hours of the events, only the wounded in the nearby regions could reach our hospital. After the initial triage at the scene, the injured patients were classified as critical, serious, or mild with a second triage. Not to increase the crowding of the ED during the secondary triage, the triage was performed in a defined area outside the $E D^{[8]}$ using the Simple Triage and Rapid Treatment (START) system. ${ }^{[9]}$ The patient flow pattern expected in disasters is the initial arrival of a large number of mildly injured patients, followed by severely injured ones transferred via the EMS. ${ }^{\left[{ }^{10]}\right.}$ However, as in our study, in a previous study with burn patients, the patient flow resembling a zigzag pattern according to on the triage scale in a short period was encountered, ${ }^{[I]}$ which can be described as the constant flow of mildly injured patients, in addition to the fewer number of severe injuries admitted at regular time intervals. The zigzag pattern of the patient flow according to the ISS seen in the coup attempt might be due to the collapse of the
EMS system and difficulties in reaching the hospital, referral of critical patients from external centers, reorganization of the EMS and redistribution of the patients to other centers after the settlement of events, and prolonged conflict in the 15 July Martyrs Bridge which is located near our hospital.

To our knowledge, our study may be the first to evaluate the patients' admission patterns according to the ISS scores due to firearm injuries. Six patients admitted to our hospital with lifethreatening injuries arrived at 00:30 AM, 03:10 AM, 03:40 AM, 03:50 AM, 04:02 AM, and 05:45 AM, respectively, leading to a peak in the ISS scores. The distribution of the patients with prolonged mass shootings should be explained to the EMS to prevent the transfer of the patients with high ISS scores to the same hospital. In our study, three patients were referred back to the referral hospital due to the lack of operation teams in our hospital to perform specific surgeries. Also, the inability to transfer patients to the ED via EMS for safety reasons led to an increase in the mortality rate. This highlights the importance of effective and on-site intervention of the EMS system, as in the Boston Marathon bombing. ${ }^{[12]}$

Although our hospital covered 10\% of all armed injuries, we observed that our patient care quality improved; however, the disaster management principles were violated due to a relatively low number of patients presenting to the ED in a short period. Fifteen patients with a mean ISS score of 4 were followed in the ED setting for eight hours or more. This finding suggests that the emergency follow-up periods of patients for a mass event may longer than expected. The factors of failure to follow disaster medicine principles can be explained by i) the lack of legal regulations for physicians regarding the mass death and injury incidents; ii) physicians' hesitancy to make decisions independently from the hospital policies; iii) difficulties in discharging patients due to lack of experienced staff; and iv) delayed or failed transfer of mildly injured patients to their residences by ambulances.

A study by Cook et al. ${ }^{[13]}$ in the United States of America on firearms between 2004 and 2013 showed that about 30,000 firearm injuries were admitted to hospitals per year, and there was approximately 2,500 death. In addition, the authors reported that males were nine-times more injured than females, 
although the mortality rate was higher in female patients. Although both male and female civilians attended the events during the July 15 incidents, the majority of the patients included in our study were males (98\%), consistent with the literature. In a literature review of patients who died from gunshot wounds, the mortality rate of the patients was reported to be high and survivable injuries were relatively low. [14] In addition, 58\% of the patients had injuries to the head and chest and $20 \%$ to the extremities. Chest and head injuries are the most common fatal injuries in $77 \%$ of the cases. ${ }^{[14,15]}$ The low mortality rate of the patients who were admitted to our hospital can be explained by the high rate of survivable injuries, as all intracranial hemorrhages arise from a fragmented bullet injury with predominantly extremity injuries.

In our study, the LOS in the hospital of the patients admitted to the ED depended on the ISS scores and trauma mechanisms. In the 2008 Mumbai terrorist attack, which can be given as an example of prolonged mass casualty, automatic weapons and explosives were used in four different regions. The terrorist attacks took nearly 60 hours, resulting in the death of 172 citizens with 304 injuries. A total of $62 \%$ of the patients were hospitalized in the general surgery, $16 \%$ in the orthopedics, $11 \%$ in the pediatric, $8 \%$ in the plastic surgery, and $1.2 \%$ in the brain surgery wards. A total of $38.5 \%$ of the patients underwent general surgery and orthopedic interventions, and the in-hospital mortality rate was $12 \%{ }^{[4]}$ The discrepancy between our study and this report can be attributed to the continuation of the mortal injury in the field, with EMS being readily available to the hospital as a result of the siege of the terrorists. In this case, the dead and major injuries were left on the scene due to safety concerns, and more survivable injuries were transferred to the hospital. Therefore, based on our experience, we suggest that hospitalization in orthopedics and plastic wards is relatively higher than in critical areas, such as general and brain surgery. In the Westgate attack, the data were obtained from the patients who applied to the first-level trauma center. The incident took four days and victims were wounded with automatic weapons. As a result, a total of 67 death and 175 injuries occurred. The hospital intervened 65 injured within the first six hours. Twenty-five patients were discharged from the ED, and 45 patients were hospitalized and treated. A total of $63 \%$ of the hospitalized patients were operated within the first 24 hours. Thirty patients underwent surgery, and the mean hospitalization duration was five days. ${ }^{[16]}$ These data are consistent with our study, indicating that prolonged duration of mass casualty is associated with higher survival rates due to minor injuries. Therefore, it can be predicted that the number of major and fatal injuries would increase in the first moments of the event, while the number of minor injuries would increase as the incident prolongs.

In our study, after the coup attempt was suppressed and the ED started to work normally, the patients who were waiting in the green area at night did not return home and applied to the green area again in the morning. The results of the our talk with the patients revealed that they considered that the hospital was the safest place in the city, and they were able to contact their families and loved ones and did not leave the hospital that affected the surge capacity of the hospital adversely. Of note, hospitals are usually considered the safest places from the point of patients' views ${ }^{[17]}$ and for the surge capacity of the hospital, it is necessary to plan areas where patients and their relatives can accommodate. ${ }^{[6]}$ In our study, the LOS in the hospital decreased after the arrival of volunteer staff to the ED, even if the ISS increased. We believe that the ability to provide emergency health care during $\mathrm{MCls}$ would increase with volunteers who are trained with standard operational procedures and hospital disaster plans. The limitation of our study was a single-center experience and we are able to evaluate only the patients who came to our hospital.

\section{Conclusion}

In conclusion, being prepared for $\mathrm{MCl}$ and following the hospital disaster planning codes does not mean that it is completely ready. Of note, the management of each disaster is unique. Planning should be structured to adapt to change situations, considering that unusual events may extend as we experienced and the patient flow according to the severity of injuries may show an unforeseen pattern. As expected, armed conflicts result in gunshot wounds, and preparations must be focused on surge capacity and a prolonged hospital stay of patients. Furthermore, additional trained volunteer support may be needed, when necessary. In our study, the LOS in the hospital decreased after the arrival of volunteer staff to the ED although the ISS increased. We believe that the ability to provide emergency health care during $\mathrm{MCls}$ would increase with volunteers who are trained with standard operational procedures and hospital disaster plans. Further large-scale studies are needed to provide new insights into the emergency health care delivery that has been addressed in this study.

\section{Acknowledgements}

The authors of this research article would like to thank all medical staff who involved with valuable contributions and efforts during the coup attempt in Turkey.

Ethics Committee Approval: Approved by the local ethics committee (date: 06.06.2017, no: 2017/0160).

Peer-review: Internally peer-reviewed.

Authorship Contributions: Concept: K.A., M.K., G.A.S.; Design: K.A., G.A.S.; Supervision: K.A., Ö.T., S.E.; Materials: M.K., A.S., E.A., Ö.E.; Data: S.E., Ö.E.; Analysis: K.A., M.K., G.A.S., E.A.; Literature search: Ö.T., Ö.E., S.E., K.A.; Writing: K.A., E.A., M.K., G.A.S.; Critical revision: K.A., M.K., G.A.S.

Conflict of Interest: None declared.

Financial Disclosure: The autors declared that this study has received no financial support. 


\section{REFERENCES}

1. Frykberg ER. Medical management of disasters and mass casualties from terrorist bombings: how can we cope? J Trauma 2002;53:201-12. [CrossRef]

2. Rodoplu U, Arnold JL, Tokyay R, Ersoy G, Cetiner S, Yücel T. Masscasualty terrorist bombings in Istanbul, Turkey, November 2003: report of the events and the prehospital emergency response. Prehosp Disaster Med 2004;19:133-45. [CrossRef]

3. Tayfur İ, Afacan MA, Erdoğan MÖ, Çolak Ş, Söğüt Ö, Genç Yavuz B, et al. Health results of a coup attempt: evaluation of all patients admitted to hospitals in Istanbul due to injuries sustained during the July 15, 2016 coup attempt. TJTES 2018;24:39-42. [CrossRef]

4. Roy N, Kapil V, Subbarao I, Ashkenazi I. Mass Casualty Response in the 2008 Mumbai Terrorist Attacks. Disaster Med Public Health Prep 2011;5:273-9. [CrossRef]

5. Bilgin NG, Mert E, Camdeviren $\mathrm{H}$. The usefulness of trauma scores in determining the life threatening condition of trauma victims for writing medical-legal reports. Emerg Med J 2005;22:783-7. [CrossRef]

6. Peleg K, Michaelson M, Shapira SC, Aharonson-Daniel L. Principles of emergency management in disasters. Adv Ren Replace Ther 2003;10:117-21. [CrossRef]

7. American College of Emergency Physicians. Health care system surge capacity recognition, preparedness, and response. Ann Emerg Med 2005;45:239. [CrossRef]

8. Hammond J. Mass Casualty Incidents: planning implications for trauma care. Scand J Surg 2005;94:267-71. [CrossRef]

9. Kahn CA, Schultz CH, Miller KT, Anderson CL. Does START triage work? An outcomes assessment after a disaster. Ann Emerg Med 2009;54:424-30, 430.e1. [CrossRef]

10. Li GQ, Hou SK, Yu X, Meng XT, Liu LL, Yan PB, et al. A descriptive analysis of injury triage, surge of medical demand, and resource use in an university hospital after 8.12 Tianjin Port Explosion, China. Chin J Traumatol 2015;18:314-9. [CrossRef]

11. Chen SY, Chaou CH, Ng CJ, Cheng MH, Hsiau YW, Kang SC, et al. Factors associated with $\mathrm{ED}$ length of stay during a mass casualty incident. Am J Emerg Med 2016;34:1462-6. [CrossRef]

12. Gates JD, Arabian S, Biddinger P, Blansfield J, Burke P, Chung S, et al. The initial response to the Boston marathon bombing: lessons learned to prepare for the next disaster. Ann Surg 2014;260:960-6. [CrossRef]

13. Cook A, Osler T, Hosmer D, Glance L, Rogers F, Gross B, et al. Gunshot wounds resulting in hospitalization in the United States: 2004-2013. Injury 2017;48:621-7. [CrossRef]

14. Smith ER, Shapiro G, Sarani B. The profile of wounding in civilian public mass shooting fatalities. J Trauma Acute Care Surg 2016;81:86-92.

15. Seçer M, Ulutaş M, Alagöz F, Uçkun ÖM, Çınar K, Yel C, et al. Relationship of biological factors to survival in spinal gunshot injuries. TJTES 2016;22:253-8.

16. Wachira BW, Abdalla RO, Wallis LA. Westgate Shootings: An Emergency Department Approach to a Mass-casualty Incident. Prehospital Disaster Med 2014;29:538-41. [CrossRef]

17. Smilowitz R, Blewett W, Williams P, Smilowitz W. Risk Management Series, Safe Rooms and Shelters. FEMA; 2006. [CrossRef]

\title{
ORIJINAL ÇALIŞMA - ÖZET
}

\section{Türkiye'de darbe girişimi esnasında kitlesel silah yaralanmasına maruz kalan hastaların özellikleri: Tek merkezli hastane deneyimi \\ Dr. Kurtuluş Açıksarı, ${ }^{1}$ Dr. Mehmet Koçak, ${ }^{2}$ Dr. Görkem Alper Solakoğlu, ${ }^{3}$ Dr. Ömer Turan, ${ }^{4}$ Dr. Samet Erinc, ${ }^{5}$ Dr. Özgür Ekinci, ${ }^{6}$ Dr. Ebuzer Aydın ${ }^{7}$}

\author{
1'stanbul Medeniyet Üniversitesi Tıp Fakültesi, Acil Tıp Anabilim Dalı, İstanbu \\ ${ }^{2}$ Sağlık Bilimleri Üniversitesi Fatih Sultan Mehmet Eğitim ve Araştırma Hastanesi, Acil Tıp Kliniği, İstanbul \\ ${ }^{3}$ Göztepe Eğitim ve Araştırma Hastanesi, Acil Tıp Kliniği, İstanbul \\ ${ }^{4}$ İstanbul Medeniyet Üniversitesi Tıp Fakültesi, Adli Tıp Anabilim Dalı, İstanbul \\ ${ }^{5}$ Sağlık Bilimleri Üniversitesi Şişli Etfal Eğitim ve Araştırma Hastanesi, Ortopedi Kliniği, İstanbul \\ ${ }^{6}$ İstanbul Medeniyet Üniversitesi Tıp Fakültesi, Genel Cerrahi Anabilim Dalı, İstanbul
}

${ }^{7}$ İstanbul Medeniyet Üniversitesi Tıp Fakültesi, Kalp ve Damar Cerrahisi Anabilim Dalı, İstanbul

AMAÇ: Türkiye, bombalama ve ateşli silah eylemleri gibi terörist saldırılarından kaynaklanan askeri ve sivil kitlesel yaralanmalar konusunda deneyimli bir ülkedir. Bu çalışmada, I5 Temmuz 2016'da gerçekleşen darbe girişiminde, ön planda ateşli silah yaralanmaları nedeniyle hastanemize başvuran hastaların ve hasta akışııı özelliklerini araştırmayı amaçladık.

GEREÇ VE YÖNTEM: Bu tanımlayıcı, geriye dönük çalışmamıza 15 Temmuz 2016 tarihinde darbe girişimi sırasında yaralanan ve acil servisimize başvuran toplam 50 hasta alındı. Hastaların demografik özellikleri, anatomik yaralanma bölgeleri, ameliyat sonrası klinik sonuçları ve hastanede yatış özellikleri araştıııldı. Yaralanma şiddetini ölçmek için Glasgow Koma Skoru (GCS), Travma ve Yaralanma Şiddet Skoru (TRISS), Kısaltılmış Yaralanma Skoru (AIS), Düzeltilmiş Travma Skoru (RTS) ve Yaralanma Şiddet Skoru (ISS) kullanıldı.

BULGULAR: Hastaların tamamına yakını erkekti (49:1). En sık yaralanma, ekstremite yaralanmasıydı (\%53). Acil servisten taburcu edilen hastalar ile hastaneye yatırılan hastaların RTS, GCS ve TRISS skorları ortalamaları arasında istatistiksel anlamlı bir fark saptanmazken ( $>>0.05$ ), ISS skoru hastanede yatanlarda daha yüksek saptandı $(p<0.00$ I). Takip ve/veya cerrahi girişim nedeniyle hastaneye yatırılan toplam 33 (\%66) hastanın beşi (\%।0) I4 günden uzun süre hastanede takip edildi. Acil serviste 12 personelin çalıştı̆ıı ilk dönemde ISS skor ortalaması $5.75 \pm 8.26$ olan sekiz hasta başvurdu. Bu hastaların üçü (\%37.5) hastaneye yatıııldı. İki saat içinde acil servise gönüllü olarak 63 sağılık çalışanı ulaştı. Acilde 75 personelin çalıştığı dönemde ISS skor ortalaması $7.76 \pm 8.29$ olan 42 hasta başvurdu. Otuz hastanın yatışı yapıldı (\%7।.4). illk ve ikinci grubun hastanede yatış süreleri

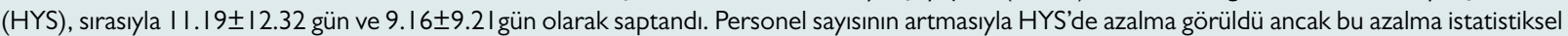
olarak anlamlı değildi $(p=0.725)$.

TARTIŞMA: Her afetin yönetimi kendine özgüdür. Ateşli silah yaralanması hazırlıklarında hastanenin yüklenme kapasitesine ve hastaların hastanede uzamış yatış süresine odaklanıımalıdır. Çalışmamızda, gönüllü personellerin acil servise ulaşması ile birlikte ISS skorları yüksek olan yaralıların hastanede kalış sürelerinin kısaldığı tespit edilmiştir. Kitlesel olaylarda, acil sağılı hizmetlerinin standart operasyonel prosedür eğitimi almış gönüllülerle artacağına inanıyoruz. Hastane afet planları, sadece acil servisler için değil tüm hastane için yeniden düzenlenmelidir.

Anahtar sözcükler: Acil servis; ateşli silah; kitlesel yaralanma olayları; yaralanma şiddet skoru.

Ulus Travma Acil Cerrahi Derg 2020;26(I):67-73 doi: 10.14744/tjtes.2019.96821 